\title{
PHOSPHATE FORMS IN PLANT AND THEIR INTERNAL BUFFERING IN FIVE SOYBEAN CULTIVARS $\mathbf{~}^{(\mathbf{1})}$
}

\author{
Hermínia E mília Prieto Martinez ${ }^{(2)}$, Roberto Ferreira Novais ${ }^{(3)}$, \\ Luciana Aparecida Rodrigues $^{(4)}$ \& Luis Vitor Silva do Sacramento ${ }^{(5)}$
}

\begin{abstract}
SUMMARY
Differences among plants in their ability to support nutritional stress periods may be caused by a differential vacuole capacity of ion storage and release and may also depend on the intensity of nutrient re-translocation under such conditions. In five soybean cultivars, submitted to eight days of P deprivation, the dry matter production and the contents of three phosphorus (P) forms inorganic $(\mathrm{Pi})$, organic $(\mathrm{Po})$, and acid-soluble total (Pts) of different plant organs were determined. Pi release velocity (RSPi) was esti mated as the tangent to the equations obtained for $\mathrm{Pi} f(t)$ at the point $t=2$ days (the mean point in the period of greatest $\mathrm{Pi}$ decrease), considering that $-\delta \mathrm{Pi} / \delta$ t expresses the rate of $\mathrm{Pi}$ release. The internal Pi buffering capacity (IBCPi) was calculated as the inverse of the RSPi. Cultivars' differences in size of the non-metabolic Pi pool, RSPi, and the ability to transport $\mathrm{Pi}$ from less to more actively metabolizing regions were evaluated. The preferential Pi source and sink compartments under limited P absorption conditions were also evaluated. The cultivar Santa Rosa showed the highest Pi storage ability when the external supply was high, and a more intensive release under low P supply conditions than IAC8 and UFV1. The cultivar Uberaba was superior to Doko in its ability to store and use $\mathrm{Pi}$. In all cultivars, upper leaves and roots were the main sink of Pi stored in the middle and lower leaves. Roots and upper leaves showed larger RSPi and lower IBCPi values than middle and lower leaves.
\end{abstract}

Index terms: phosphorus, phosphate fractions, phosphorus deprivation, nutritional stress.

\footnotetext{
(1) Recebido para publicaçao em maio de 2003 e aprovado em outubro de 2004.

(2) Professora Adjunta do Departamento de Fitotecnia da Universidade Federal de Viçosa - UFV. Av. P.H. Rolfs s/n, CEP 36571000 Viçosa (MG). E-mail: herminia@ufv.br

(3) Professor Titular do Departamento de Solos da UFV. Email: rfnovais@ufv.br

(4) Professora bolsista do Laboratório de Ciência do Solo da Universidade Estadual Norte Fluminense - UENF. Av. Alberto Lamego 2000, CEP 28015-410 Campos dos Goytacazes (RJ ). E-mail: Iua@ienf.br

(5) Professor do Departamento de Toxicologia da Faculdade de Ciências Farmacêtuticas da Universidade Estadual Paulista J ulio de Mesquita Filho - FCF-UNESP. Rodovia Araraquara, J aú, km 1. CEP 14801-902 Araraquara (SP). E-mail: Ivss@fcfar.unesp.br
} 


\title{
RESUMO: FRAÇÕES FOSFATADAS E CAPACIDADE TAMPÃO DE FÓSFORO EM CINCO CULTIVARES DE SOJ A
}

\begin{abstract}
Diferenças inter e intra-específicas na habilidade de suportar períodos de estresse nutricional podem dever-seà capaci dadedearmazenar eliberar íons dos vacúol os, e, ou, à intensidade de retransl ocação de nutrientes em tais condi ções. Nestetrabal ho, pretendeuseavaliar diferenças varietais quanto ao tamanho do "pool " não-metaból ico dePi; vel oci dade de liberação do Pi previamente armazenado (VLPi), quando o P citoplasmático cai a um valor limite; capacidadedetransportar Pi deregiões menos ati vas para aquel as mais ativas metabolicamente e definir compartimentos que são preferencialmente fontes e os que são preferencial mentedrenos para o Pi, em condições de absorçãolimitada deP. Aval iaram-se a produção dematéria seca eos teores internos dePi, orgânico (Po) etotal sol úvel em áci do (Pts), de diferentes órgãos de plantas dos cultivares desoja (Glycine max L. Merrill) Santa Rosa, Uberaba, IAC8, Doko e UFV1, submetidos a oi to dias de omissão do elemento. A VLPi foi estimada como tangente às equaç̃os obtidas para Pi como função do perído de omissão no ponto médio do período de omissão em quehouve mai or decréscimo em Pi (zero a quatro dias deomissão deP), $\mathrm{t}=$ dois dias, considerando-seque- $\delta \mathrm{Pi} / \delta \mathrm{t}$ expressa a vel ocidade deliberação dePi. A capacidadeinterna detamponamento dePi (CTIPi) foi calculada como o inverso da VLPi. O cultivar Santa Rosa apresentou maior capacidade de armazenar Pi, quando o suprimento externo foi al to, liberando-o mais intensamentesob condi ções de bai xo suprimento de P que os cultivares I AC8 eUFV1. O cultivar Uberaba mostrou-sesuperior ao Doko em sua habilidade dearmazenar e utilizar o $\mathrm{Pi}$. Fol has superiores mostraram ser o principal dreno para o Pi armazenado em fol has medianas e inferiores, seguidas por raízes e caules. Raízes comportaram-se como fontes ou drenos para o Pi. Raízes efol has superiores apresentaram maiores (VLPi) emenores val ores deCTI Pi quefol has medianase fol has inferiores, sendo o caule o comparti mento com menor VLPi emai or CTIPi. Dentreas variedades, as diferenças foram pequenas, destacando-se a mai or VLPi e menor CTIPi do cultivar Santa Rosa. O cultivar Doko apresentou a menor VLPi e mai or CTIPi, enquanto U beraba, I AC8 eUFV1 ocuparam posi ção intermediária quanto a essas características.
\end{abstract}

Termos de indexação: fósforo, frações fosfatadas, omissão defósforo, estresse nutricional.

\section{INTRODUCTION}

Nutrition and growth can differ among species and cultivars even under similar soil fertility conditions. Better nutritional and growth status may bea result of a moreefficient nutrient absorption and, or, use by a cultivar. This variable nutritional behavior was reported to be genetically controlled (Raghothama, 1999). The involved processes are related to the plant and to the root-soil interface. Among the intrinsic plant mechanisms, internal allocation and use of nutrients in the metabolism and growth, which are dependent on re-translocation and re-use under stress conditions, play a fundamental role. Another very important factor is the release of ions from the vacuoles under nutritional stress (Bieleski \& Ferguson,1983).

Several papers report differences in $\mathrm{P}$ absorption and use by plants. In soybean, differences were observed in relation to the soil capacity characteristics, with highest accumulation of inorganic $\mathrm{P}(\mathrm{Pi})$ in vacuoles of plants cultivated in soils which provided high $P$ concentration in solution (Muniz et al., 1985). When the P supply is high, the plant is able to accumulate $\mathrm{Pi}$ in the vacuoles. On the other hand, when the supply is limited either by nutrient insufficiency or by low soil moisture(limited transport), the previously accumulated $\mathrm{Pi}$ is rel eased to the metabolic pools to meet $\mathrm{P}$ demands (Bieleski \& Ferguson, 1983; Lee \& Ratcliffe, 1983, 1993; Ratcliffe, 1994; Raghothama, 1999). Under adequate supply, 80 to $95 \%$ of the cellular P is found in the vacuole, and only 5 to $15 \%$ make up the metabolic or cytoplasmatic pool (Glass \& Siddqi, 1984).

According to Raghothama (1999), a minimum concentration of $P$ in the cytoplasm is critical to maintain the normal plant metabolism. Therefore, a strong tendency to maintain a constant $\mathrm{P}$ concentration in the cytoplasm is observed, in spite of the great variation in the external availability (Glass \& Siddqi, 1984).

Based on these considerations, it is believed that the size of the non-metabolic pool and the plant species/cultivar's ability to translocatethis pool from one compartment to another certainly affect its adaptability to and survival under nutritional stress conditions. The present study was carried out to evaluate the size of the non-metabolic (vacuole Pi) $\mathrm{P}$ pool, and in the capacity to release Pi when the cytoplasmatic $P$ falls to a limiting value by soybean 
cultivars. A further aim was to determine which organs are preferentially sources and sinks of $\mathrm{Pi}$ under limited $\mathrm{P}$ absorption conditions.

\section{MATERIAL AND METHODS}

Seeds of soybean (GlycinemaxL. Merrill) 'Santa Rosa', 'U beraba', 'I AC8', 'Doko' and 'UFV1' cultivars were germinated in washed sand. Seven-day old seedlings were transferred to $9.5 \mathrm{~L}$ plastic pots containing a completefull strength Clark's nutrient solution (Clark, 1975) with a modified P concentration $\left(0.08 \mathrm{mmol} \mathrm{L}^{-1}\right.$ of $\mathrm{P}$ ) where they grew for 22 days. After this period, the plants were transferred to pots of equal volume containing Clark's nutrient solution with high $\mathrm{P}\left(0.5 \mathrm{mmol}^{-1}\right)$ for $48 \mathrm{~h}$. They werethen transferred back to pots containing a nutrient solution with low $\mathrm{P}\left(0.08 \mathrm{mmol}^{-1}\right)$, and after $2 \mathrm{~h}$ in this solution they were transferred to Clark's nutrient solution with no $\mathrm{P}$. On this occasion, four plots were collected to determine tissue $\mathrm{P}$ concentrations. These samples corresponded to zero days of $P$ omission. The other tissue samples were extracted 1, 2, 4, and 8 days after transferring the seedlings to no $P$ nutrient solution.

The nutrient solutions were continuously aerated, and the $\mathrm{pH}$ was measured daily and maintained between 5.0 and 5.5 by addition of $\mathrm{HCl}$ or $\mathrm{NaOH}$. The nutrient solutions were al ways renewed when $\mathrm{K}$ and, or, $\mathrm{P}$ decreased to $a$ valuethat was $30 \%$ lower than the initial one. Each experimental plot consisted of one $9.5 \mathrm{~L}$ pot with two plants. The experiment was carried out in a glasshouse at the Soil Science Department of the Viçosa Federal University, in Viçosa (MG), Brazil. The treatments were a $5 \times 5$ factorial (five soybean cultivars and five $\mathrm{P}$ omission periods) in a randomized complete block design, with four replicates.

At the end of each $\mathrm{P}$ omission period, the plants of four plots were collected and sampled. For tissue sampling, the leaves of one plant per plot were divided in three equal parts (upper leaves (UL), middle leaves $(M L)$ and lower leaves $(L L)$ ). Stems $(\mathrm{S})$ and roots $(\mathrm{R})$ were also collected. These plant parts were washed in distilled water, dried at $70{ }^{\circ} \mathrm{C}$ and weighed. The second plant of the plot was similarly divided, and samples of about $1 \mathrm{~g}$ of fresh matter of each component was collected, weighed, placed in test tubes containing $2 \mathrm{~mL}$ of $\mathrm{HClO}_{4}$ ( $\left.0.2 \mathrm{~mol} \mathrm{~L}^{-1}\right)$ and immediately frozen. Thesesamples were later macerated in $\mathrm{HClO}_{4}\left(0.2 \mathrm{~mol} \mathrm{~L}^{-1}\right)$ at $4{ }^{\circ} \mathrm{C}$, centrifuged at $5,000 \mathrm{xg}$, and used for the determination of the phosphatefraction $(\mathrm{Pi})$, soluble in acid, in the supernatant (Figure 1 ). Thetotal acidsoluble phosphate (Pts) was obtained after nitroperchloric digestion of a $10 \mathrm{~mL}$ aliquot of the extract obtained by maceration. The acid-soluble organic $P$ (Po) was calculated by the difference between the Pts and Pi contents, based on Hogue et al. (1970). All tissue $\mathrm{P}$ concentrations were determined col orimetrically by reduction of the phosphomolibdate complex by ascorbic acid.

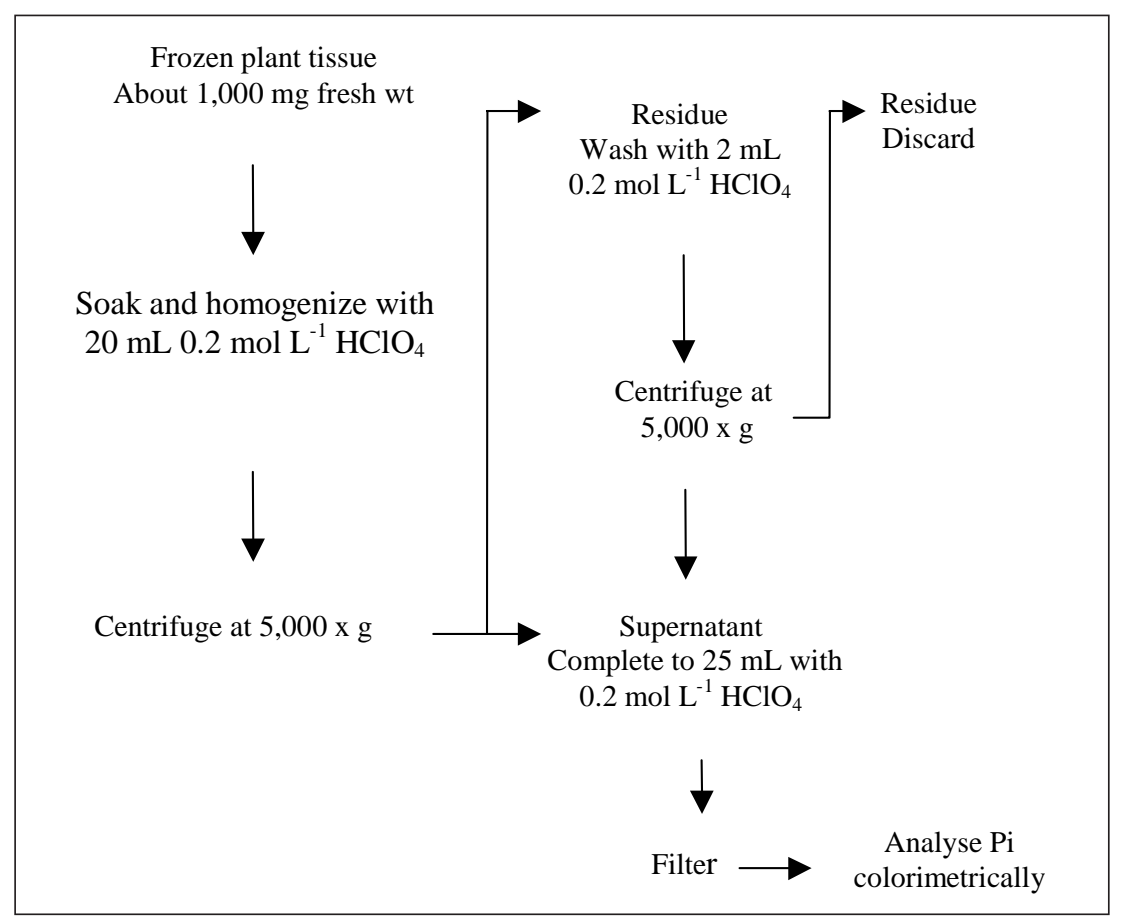

Figure 1. Inorganic P (Pi) fractionation scheme in soybean tissue. Based on Hogue et al. (1970) 
Inorganic $\mathrm{P}$ and $\mathrm{Po}$ concentration values, as dependent variables of the days of $\mathrm{P}$ omission in the nutrient solution, were submitted to variance and regression analyses. The highest degree model was chosen based on the $F$ test and on the determination coefficient. When nosignificant treatment effect was detected or no model fitted the data, it was considered that the Pi and Po concentration did not vary as a function of time ( $t$ ) of $P$ omission. A constant estimated by the mean of the observed values was then obtained.

Considering that $-\delta \mathrm{Pi} / \delta$ t expresses the velocity of $\mathrm{Pi}$ release and that the greatest reduction of the $\mathrm{Pi}$ content in all plant parts occurred between 1 and 4 days of $\mathrm{P}$ omission, $\mathrm{Pi}$ release vel ocity (RSPi) was estimated as being the tangent to the equations obtained for $\mathrm{Pi} f(\mathrm{t})$ at the point $\mathrm{t}=2$ days (the mean point in the period of greatest $\mathrm{Pi}$ decrease). The internal Pi buffering capacity (IBCPi) was cal culated as theinverse of theRSPi. Plant organ mean values of RSPi and IBCPi were obtained as arithmetic average among cultivars (Novais \&.Smyth, 1999).

Data of leaves, stems, shoot, root, and whole plant dry matter were submitted to analyses of variance and the means were compared by the Tukey's test to assess cultivar differences.

\section{RESULTS AND DISCUSSION}

The soybean plants not submitted to $P$ omission stress presented estimated $\mathrm{Pi}$ concentration values varying from 284 to $666 \mathrm{mg} \mathrm{kg}^{-1}$ of fresh matter in the various analyzed parts (Figures 2 to 4 ).

Roots were the compartment with highest $\mathrm{Pi}$ concentration, followed by the upper and middle leaves; lower leaves and stems were the compartments with the lowest Pi concentrations. Inorganic $P$ concentration in all plant parts decreased in a quadratic form, with a more drastic reduction at the beginning of the $P$ omission period (0 to 4 days). After one day of $P$ omission, there was a high percentage reduction of $\mathrm{Pi}$ concentration $(24,21$, and $23 \%$, respectively) in UL (533 to $406 \mathrm{mg} \mathrm{kg}^{-1}$ ), LL (364 to $287 \mathrm{mg} \mathrm{kg}^{-1}$ ), and R (600 to $465 \mathrm{mg} \mathrm{kg}^{-1}$ ). After four days of omission, the $\mathrm{Pi}$ reduction in $\mathrm{R}$ (600 to $171 \mathrm{mg} \mathrm{kg}^{-1}$ ) and UL (533 to $153 \mathrm{mg} \mathrm{kg}^{-1}$ ) was higher than that in LL (364 to $129 \mathrm{mg} \mathrm{kg}^{-1}: 72,71$ and $65 \%$ on average, respectively). After eight days of $P$ omission, the greatest percentage of $P$ i reduction was found for the roots (average of 600 to $45 \mathrm{mg} \mathrm{kg}^{-1}$, $93 \%$ ), followed by S (360 to $45 \mathrm{mg} \mathrm{kg}^{-1}$ ), UL (533 tol13 $\mathrm{mg} \mathrm{kg}^{-1}$ ) LL (364 to $91 \mathrm{mg} \mathrm{kg}^{-1}$ ) and ML (430 to $106 \mathrm{mg} \mathrm{kg}^{-1}$ ), averaging $88,79,75$, and $75 \%$, respectively, in relation to the plants not submitted to the stress (Figures 2 to 4 ).

Based on the variations of the $P$ fractions in the plant parts during the period of $P$ omission, it is possible to infer that the $\mathrm{Pi}$ release from the non- metabolic to the metabolic pool was initially more intensive in $U L, L L$, and $R$. As the omission period persisted, there were higher percentages of $\mathrm{Pi}$ reduction in the stems. However, the role of the stems as Pi source is doubtful in view of their small initial reserve compared to other plant parts, especially R and UL (Figures 2 to 4 ).

Higher Pi contents in $\mathrm{R}$ and $\mathrm{UL}$ of plants under adequate $P$ supply show that young tissues have $a$ greater storage capacity. Also, their greater metabolic activity could make them stronger sinks for theabsorbed P. This causes higher cytoplasmatic
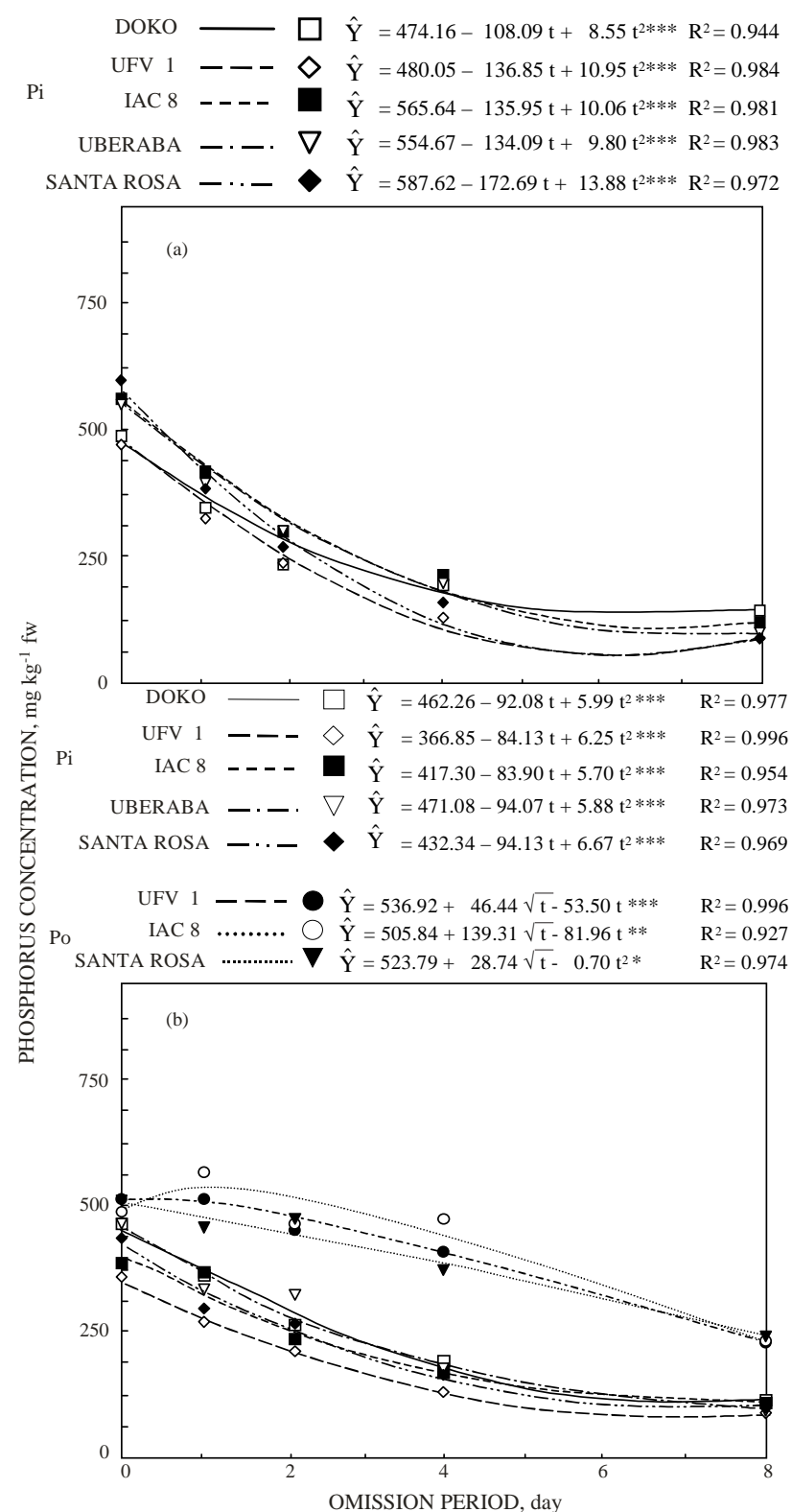

Figure 2. Inorganic $\mathbf{P}(\mathrm{Pi})$ and organic $\mathbf{P}$ (Po) concentration in fresh matter of the upper leaves (a) and middle leaves (b) of five soybean cultivars as a function of the $P$ omission period. (*,**,***: Significant at 10,5 and $1 \%$, respectively). 

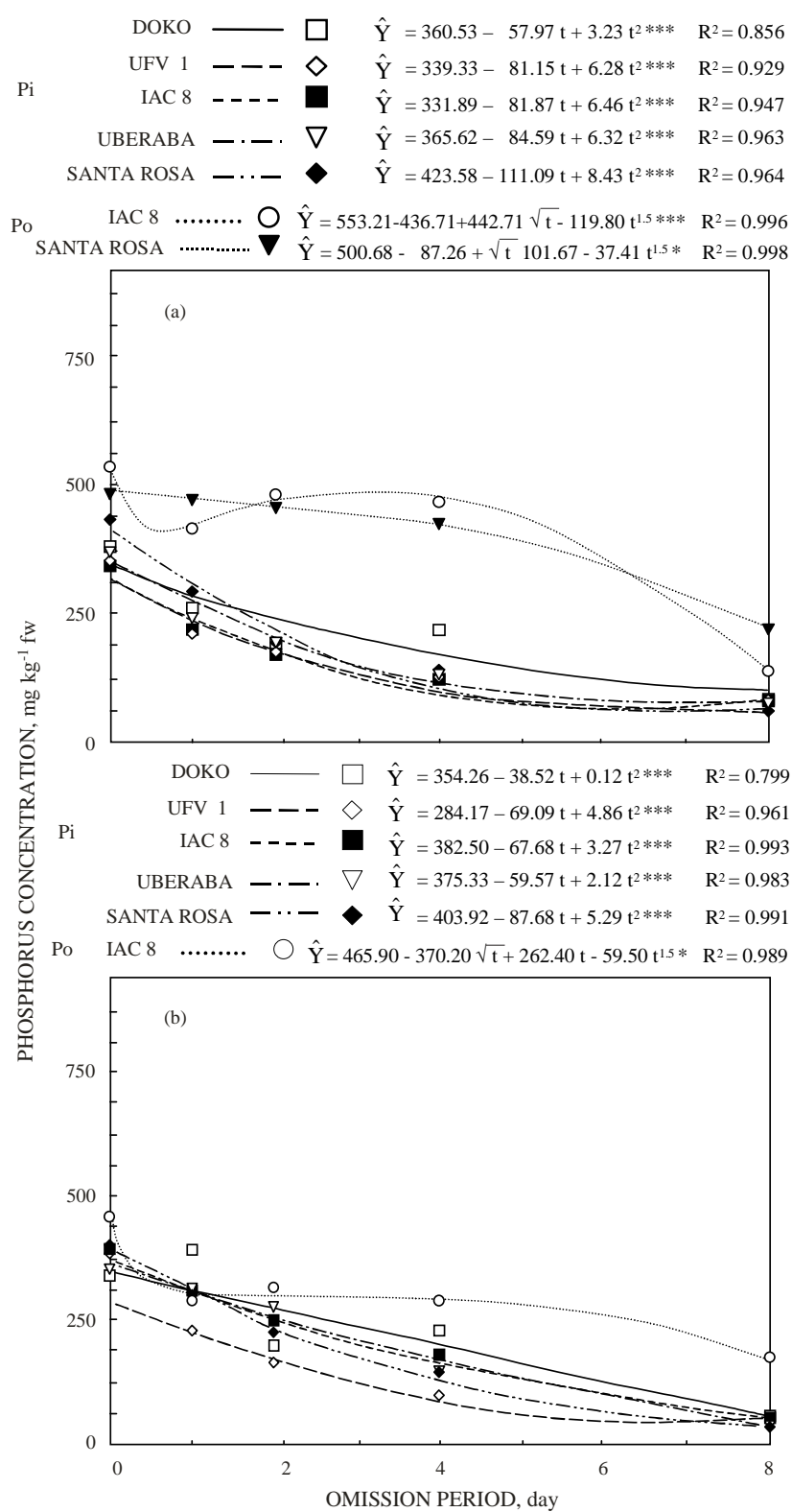

Figure 3. Inorganic $P(P i)$ and organic $P(P o)$ concentration in fresh matter of the lower leaves (a) and stems (b) of five soybean cultivars as a function of the $P$ omission period. (*,***: Significant at 10 and $1 \%$, respectively).

P concentrations and triggers the mechanisms that operate at thetonoplast level and provide regulation for the cytoplasm-vacuole and vacuole-cytoplasm fluxes (Glass \& Siddqi, 1984 and Clarkson, 1985). According to Glass \& Siddqi (1984) and Clarkson (1985), fluxes are mediated by adjustments in the turnover rate or in the quantity of active carriers. Raghothama (1999) reported that this transport is ATP-dependent and that the existence of a specific $\mathrm{Pi}$ channel or of a symport-type transport mechanism cannot be disregarded.
After the elimination of $\mathrm{P}$ influx from theexternal solution to the roots (zero day of $\mathrm{P}$ omission), it is plausibleto suppose that all subsequent growth was due to the mobilization and use of stored $\mathrm{Pi}$. Thus the sharp drop of Pi contents in R, S and UL was caused by the release of $\mathrm{Pi}$ and by the growth of new young tissues with a very small $\mathrm{P}$ reserve. For $M L$ and $L L$, the release of the reserves must have been the determining event in the drop of the stored Pi concentrations. R, S and UL were, in this order, the preferential sinks for the stored $\mathrm{Pi}$ under conditions of interrupted P absorption. Alves (1994) observed that roots are the strongest Pi and sugars sinks in maize plants under omission of this element.

Bieleski \& Ferguson (1983) stated that most of the $\mathrm{P}$ moves towards the young growing leaves, flowers, fruits, or buds. Raghothama (1999) reported that this behavior may be altered during plant growth under $\mathrm{P}$ stress, and that compartments which are sources can become sinks. In moderately stressed potato plants exposed to $\mathrm{Pi}$, the transport to the shoot increased, while in severely stressed plants, Pi was retained in the roots (Cogliatti \& Clarkson, 1983). Martinez et al. (1993a) and Alves (1994) found that the shoot and not the root was the main sink in soybean and maize plants submitted to 8 and 12 days of $\mathrm{P}$ omission, respectively.

Under conditions of continuous $P$ supply the Santa Rosa and U beraba cultivars generally showed the highest Pi concentrations and UFVI the lowest

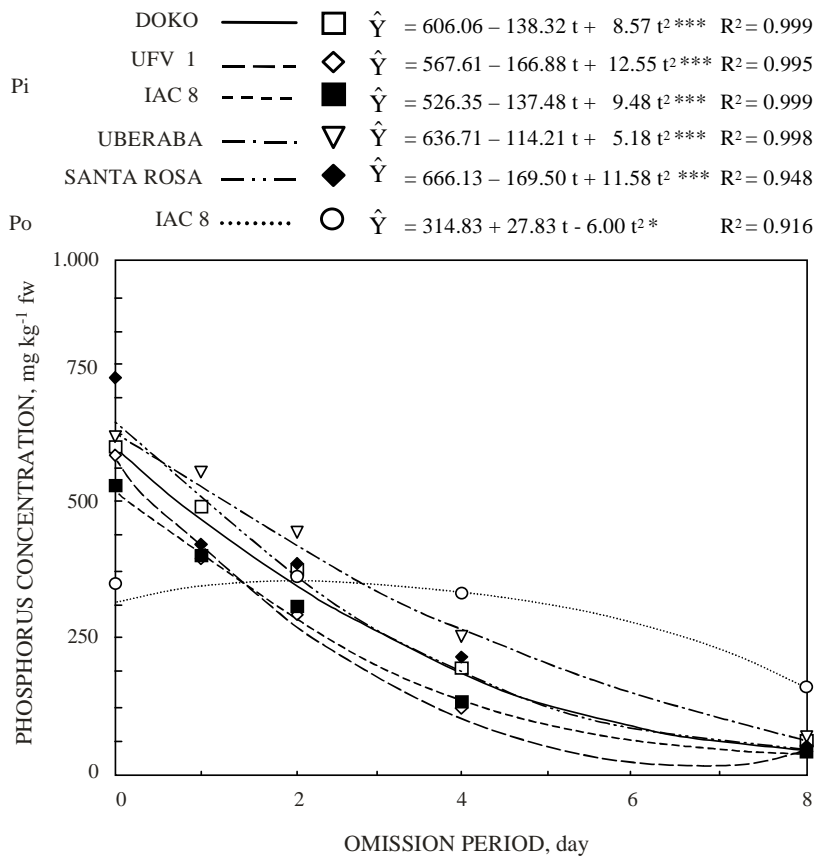

Figure 4. Inorganic $P(P i)$ and organic $P(P o)$ concentration in root fresh matter of five soybean cultivars as a function of the $P$ omission period. $(*, * * *$ : Significant at 10 and $1 \%$, respectively). 
ones. The IAC8 and Doko cultivars had Pi concentrations in-between and not significantly different from these two groups (Table 1).

The estimated values of Po concentration in fresh matter of plant components well-supplied with P varied from 133 in roots to $708 \mathrm{mg} \mathrm{kg}^{-1}$ in upper leaves and showed an increasing order for $R, S, L L$, $M L$, and UL (Figures 2 to 4 ).

Organic $\mathrm{P}$ was the fraction with the smallest variation during the eight days of $\mathrm{P}$ omission, stable in the UL of all cultivars ( $\hat{Y}=\bar{Y}=627 \mathrm{mg} \mathrm{kg}^{-1}$ for 'Santa Rosa'; $\hat{\mathrm{Y}}=\overline{\mathrm{Y}}=708$ for 'U beraba'; $\hat{\mathrm{Y}}=\overline{\mathrm{Y}}=631$ for 'IAC8'; $\hat{\mathrm{Y}}=\overline{\mathrm{Y}}=637$ for 'UFV 1' and $\hat{\mathrm{Y}}=\overline{\mathrm{Y}}=474$ for 'Doko'), $M L$ of 'U beraba' ( $\hat{Y}=\bar{Y}=434$ ) and 'Doko' ( $\hat{Y}=\bar{Y}=280), L L$ of 'U beraba' $(\hat{Y}=\bar{Y}=399)$, 'UFV $I^{\prime}(\hat{Y}=\bar{Y}=404)$ and 'Doko' ( $\left.\hat{Y}=\bar{Y}=279\right)$, and S and R of 'Santa Rosa'( $\hat{Y}=\bar{Y}=301 ; \hat{Y}=\bar{Y}=288)$, 'U beraba'(yc =yt =299; yc $=y t=318)$, 'UFV I' $(\hat{\mathrm{Y}}=\overline{\mathrm{Y}}$ $=267 ; \hat{\mathrm{Y}}=\overline{\mathrm{Y}}=308)$ and 'Doko' $(\hat{\mathrm{Y}}=\overline{\mathrm{Y}}=178 ; \hat{\mathrm{Y}}=\overline{\mathrm{Y}}=$ 133). The greatest mean relative reduction were 36 and $32 \%$ for $M L$ and $L L$, followed by reductions of 20 and $12 \%$ for $S$ and $R$, respectively (F igures 2 to 4 ). UL and R compartments, with the highest metabolic activity, showed a greater stability of Po content, probably at the expense of their own and also of $\mathrm{Pi}$ content in the ML, LL, and S compartments.

The observed behavior of Po corroborates previous discussions on the Pi concentration. The root Po was proportionally less reduced than Po in $\mathrm{S}$, although that in $\mathrm{R}$ was observed to represent a weaker sink for the Pi released by $M L$ and $L L$ than the $\mathrm{S}$. This can be explained by diverting greater initial $\mathrm{Pi}$ reserve in $\mathrm{R}$ tissues, which was used to maintain the root cytoplasmatic pool, instead of exporting it to the shoot. This agrees with Bieleski \& Ferguson, (1983) and Clarkson, (1985) who pointed out that when absorption is limited, a small $\mathrm{Pi}$ influx is retained by the roots, maintaining their growth at the expense of other plant parts and of the reduction of the shoot:root ratio. Under stress, the $\mathrm{S}$ compartment retained proportionally more Pi than theamount that was translocated to the R, thus representing a stronger sink than the R. Bieleski \& Ferguson (1983) reported that ${ }^{32} \mathrm{P}$ applied to a $\mathrm{P}$ deficient leaf was retained to a greater extent than exported. Clarkson (1985) suggested that the highest retention in roots under conditions of limited absorption was due to thefact that the roots liecloser to the supply source. Raghothama (1999) argued that the stress intensity could mould the plant response, altering the source-sink relationship.

Before $\mathrm{P}$ omission began, Po concentration in the $U L$, the plant organ that had the highest metabolic activity, was the highest (mean of $615 \mathrm{mg} \mathrm{kg}^{-1}$ ), and it was the lowest in S (mean of $302 \mathrm{mg} \mathrm{kg}^{-1}$ ) and R (mean of $272 \mathrm{mg} \mathrm{kg}^{-1}$ ), with ML (mean of $456 \mathrm{mg} \mathrm{kg}^{-1}$ ) and LL (mean of $427 \mathrm{mg} \mathrm{kg}^{-1}$ ) showing intermediate concentrations (Figures 2 to 4 ). After 8 days of $P$ omission, the UL continued with higher Po contents (mean of $615 \mathrm{mg} \mathrm{kg}^{-1}$ ) than those of the remaining organs (means of 289, 290, 243, and $240 \mathrm{mg} \mathrm{kg}^{-1}$ for $M L, L L, S$, and $R$ respectively), while the Po of $M L$ and $L L$ were close to that of $S$ and $R$. It is important to note that the whole root system was analyzed, and the observed Po contents werethereforeaverage concentrations that include parts with a high metabolic activity, such as new and thin tips, and parts with low metabolic activity, such as mature and thick parts of roots.

Table 1. I norganic P (Pi) and organic P (Po) concentration in upper, middle and lower leaves, stems, and roots of soybean cultivars grown in complete nutrient solution for $\mathbf{3 1}$ days

\begin{tabular}{|c|c|c|c|c|c|c|}
\hline $\begin{array}{l}\text { Phosphate } \\
\text { fraction }\end{array}$ & Plant part & Santa Rosa & Uberaba & IAC 8 & UFV 1 & Doko \\
\hline & & & -1 & fresh m & - & 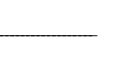 \\
\hline \multirow[t]{5}{*}{$\mathrm{Pi}$} & Upper leaves (UL) & $622 \mathrm{~A}$ & $579 A B$ & $584 \mathrm{AB}$ & $502 \mathrm{~B}$ & $505 \mathrm{~B}$ \\
\hline & Middle leaves (ML) & $455 \mathrm{AB}$ & $483 \mathrm{~A}$ & $397 \mathrm{AB}$ & $374 \mathrm{~B}$ & $477 \mathrm{~A}$ \\
\hline & Lower leaves (LL) & $446 \mathrm{~A}$ & $388 \mathrm{AB}$ & $356 \mathrm{~B}$ & $369 \mathrm{~B}$ & $397 A B$ \\
\hline & Stems (S) & $416 \mathrm{~A}$ & $363 A B$ & $394 A B$ & $383 \mathrm{C}$ & $334 \mathrm{BC}$ \\
\hline & Roots (R) & $724 \mathrm{~A}$ & $615 \mathrm{AB}$ & $525 \mathrm{~B}$ & $583 \mathrm{~B}$ & $599 A B$ \\
\hline \multirow[t]{5}{*}{ Po } & U pper leaves (UL) & $640 \mathrm{ABC}$ & 698 AB & $797 \mathrm{~A}$ & $527 \mathrm{BC}$ & $425 \mathrm{C}$ \\
\hline & Middle leaves (ML) & $527 \mathrm{~A}$ & $539 \mathrm{~A}$ & $505 \mathrm{~A}$ & $536 \mathrm{~A}$ & 345 B \\
\hline & Lower leaves (LL) & $500 \mathrm{~A}$ & $436 \mathrm{~A}$ & $554 \mathrm{~A}$ & $520 \mathrm{~A}$ & 305 B \\
\hline & Stems (S) & 347 B & $354 \mathrm{~B}$ & $467 \mathrm{~A}$ & 318 B & $172 \mathrm{C}$ \\
\hline & Roots (R) & $297 \mathrm{AB}$ & $383 \mathrm{~A}$ & $339 A B$ & $251 \mathrm{~B}$ & $121 \mathrm{C}$ \\
\hline
\end{tabular}

For each variable, means followed by the same letter in the same line did not statistically differ by the Tukey test (P <0.05). 
The results discussed above show that the younger shoot and root tissues of the studied cultivars had a higher ability to store the excess of $\mathrm{Pi}$ absorbed under adequate supply. On the other hand, when the supply was interrupted, R, S, and $U L$ were the main sink for the released $\mathrm{Pi}$.

Without $\mathrm{P}$ deprivation, in general, the Uberaba and IAC 8 cultivars showed the highest Po concentrations, followed by Santa Rosa. UFV 1 and especially Doko cultivars, showed the lowest Po concentrations (Table 1).

The concept of plant IBCPi was enunciated by Novais \& Smyth (1999) in anal ogy to what occurs in soils. According to these authors the Pi content as a function of the period of $P$ omission may be considered a measure of the IBCPi. The IBCPi will be higher as the slope of the equation that expresses this relationship is lowered. In this study the R was the compartment with highest RSPi and lowest IBCPi values, followed by UL (Table 2 ). This confirms the observation that these compartments are, concomitantly, important sources and sinks of $\mathrm{Pi}$. The ML and LL showed lower RSPi and higher $I B C P i$ values than $U L$ and $R$, while the $S$ had the lowest observed RSPi and highest IBCPi values. 'Santa Rosa' had the highest Pi reserve (Table 1) at the beginning of $\mathrm{P}$ omission and also the lowest internal $P$ buffering, that is, the highest $P$ i release vel ocity from its compartments in order to keep the metabolic pools. Under short intervals of nutritional stress, this can represent an adaptive advantage of this cultivar. 'U beraba' had a similar Pi reserve as 'Santa Rosa', but its capacity to rel ease reserves to the metabolic pool immediately after starting the stress was lower. 'IAC 8', in spite of a lower Pi reservethan ' $U$ beraba', presented similar RSPi and IBCPi values to 'U beraba' and to 'UFV 1'. The Pi reserve of 'UFV 1 ' was the smallest among the studied cultivars. 'Doko' had an intermediate Pi reserve, but the greatest buffering capacity and the smallest RSPi value compared to the others, especially in the UL and S compartments (Tables 1 and 2). Novais \& Smyth (1999) presented the IBCPi of two eucalyptus species: The IBCPi of Eucalyptus cloesiana, a species originating from fertile soil and high annual rainfall regions of Australia, was $0.0060 \mathrm{~kg}^{2}$ day $\mathrm{mg}^{-1}\left(\mathrm{RSPi}=166,67 \mathrm{mg} \mathrm{kg}^{-1}\right.$ day $^{-1}$, while that of $E$. camaldulensis, which is found in semi-arid regions with low annual rainfall, was $0.0472 \mathrm{~kg}$ day mg-1 $\left(\mathrm{RSPi}=21.19 \mathrm{mg} \mathrm{kg}^{-1}\right.$ day $\left.^{-1}\right)$. This suggests that internal buffering is, even when accompanied by growth restriction due to limited supply, a mechanism that guarantees survival under low $P$ availability.

The analysis of dry matter accumulation (Table 3 ) revealed that at the beginning of $\mathrm{P}$ omission there were no significant differences between the cultivars for any of the plant parts or even in the whole plant. At the end of the $8^{\text {th }}$ day of $P$ deprivation, 'Doko' presented less leaf, shoot and whole plant dry matter accumulation than 'Santa Rosa', and less root dry matter than 'UFV 1', which was accompanied by a slower Pi release and higher internal buffering for $\mathrm{Pi}$, resulting in a greater growth loss dueto P omission (Table 2). 'Santa Rosa' presented the highest RSPi value and largest whole plant dry matter production at the end of the eightday period of $P$ omission stress. The latter value was not significantly different from those of 'UFV 1', 'Uberaba' and 'I AC 8' (Tables 2 and 3).

Table 2. Inorganic phosphor us release velocity (RSPi) and internal Pi buffering capacity (IBCPi) in upper $(U L)$, midlle (ML) and lower leaves (LL), stems (S), and roots (R) of soybean plants cultivated in nutrient solution

\begin{tabular}{|c|c|c|c|c|c|c|}
\hline Cultivar & Unit. & $\mathbf{U L}$ & ML & $\mathbf{L L}$ & $\mathbf{S}$ & $\mathbf{R}$ \\
\hline Santa Rosa & $\begin{array}{l}\left.\text { RSPi (mg kg }{ }^{-1} \text { day }^{-1}\right) \\
\text { IBCPi (kg day mg-1) }\end{array}$ & $\begin{array}{l}58.59 \\
0.017\end{array}$ & $\begin{array}{l}33.72 \\
0.030\end{array}$ & $\begin{array}{l}38.68 \\
0.026\end{array}$ & $\begin{array}{l}33.26 \\
0.030\end{array}$ & $\begin{array}{l}61.59 \\
0.016\end{array}$ \\
\hline Uberaba & $\begin{array}{l}\text { RSPi (mg kg-1 day-1) } \\
\text { IBCPi (kg day mg-1) }\end{array}$ & $\begin{array}{l}47.44 \\
0.021\end{array}$ & $\begin{array}{l}35.27 \\
0.028\end{array}$ & $\begin{array}{l}29.65 \\
0.034\end{array}$ & $\begin{array}{l}25.54 \\
0.039\end{array}$ & $\begin{array}{l}46.74 \\
0.021\end{array}$ \\
\hline IAC-8 & $\begin{array}{l}\text { RSPi (mg kg-1 day-1 } \\
\text { I BCPi (kg day mg } \text { mg-1) }^{-1}\end{array}$ & $\begin{array}{l}47.85 \\
0.021\end{array}$ & $\begin{array}{l}30.55 \\
0.033\end{array}$ & $\begin{array}{l}28.01 \\
0.036\end{array}$ & $\begin{array}{l}27.30 \\
0.037\end{array}$ & $\begin{array}{l}49.78 \\
0.020\end{array}$ \\
\hline UFV-1 & $\begin{array}{l}\text { RSPi (mg kg-1 day-1) } \\
\text { IBCPi (kg day mg-1) }\end{array}$ & $\begin{array}{l}46.52 \\
0.021\end{array}$ & $\begin{array}{l}29.56 \\
0.034\end{array}$ & $\begin{array}{l}28.01 \\
0.036\end{array}$ & $\begin{array}{l}24.82 \\
0.040\end{array}$ & $\begin{array}{l}58.34 \\
0.017\end{array}$ \\
\hline Doko & $\begin{array}{l}\text { RSPi (mg kg-1 day-1) } \\
\text { IBCPi (kg day mg-1) }\end{array}$ & $\begin{array}{l}36.94 \\
0.027\end{array}$ & $\begin{array}{l}34.06 \\
0.029\end{array}$ & $\begin{array}{l}22.52 \\
0.044\end{array}$ & $\begin{array}{l}19.02 \\
0.053\end{array}$ & $\begin{array}{l}52.02 \\
0.019\end{array}$ \\
\hline Mean & $\begin{array}{l}\text { RSPi (mg kg-1 day-1) } \\
\left.\text { IBCPi (kg day } \mathrm{mg}^{-1}\right)\end{array}$ & $\begin{array}{l}47.47 \\
0.022\end{array}$ & $\begin{array}{l}32.63 \\
0.031\end{array}$ & $\begin{array}{l}29.37 \\
0.035\end{array}$ & $\begin{array}{l}25.99 \\
0.040\end{array}$ & $\begin{array}{l}53.69 \\
0.019\end{array}$ \\
\hline
\end{tabular}


Table 3. Dry matter production by leaves, stems, shoots, roots, and whole plant of five soybean cultivars cultivated for $\mathbf{3 1}$ days in complete nutrient solution or submitted to $\mathbf{8}$ days of phosphorus omission

\begin{tabular}{|c|c|c|c|c|c|c|c|}
\hline \multirow{2}{*}{ Plant part } & \multirow{2}{*}{$\begin{array}{c}\text { Omission } \\
\text { period }\end{array}$} & \multicolumn{5}{|c|}{ Cultivar } & \multirow{2}{*}{ vc } \\
\hline & & Santa Rosa & Uberaba & IAC8 & UFV1 & Doko & \\
\hline & day & 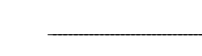 & 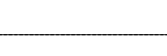 & $\mathrm{mg} \mathrm{plant}^{-1}$ & 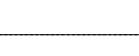 & 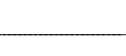 & $\%$ \\
\hline \multirow{2}{*}{ Leaves } & 0 & $1695 \mathrm{~A}$ & $1307 \mathrm{~A}$ & $1450 \mathrm{~A}$ & $1577 \mathrm{~A}$ & $1435 \mathrm{~A}$ & 15.2 \\
\hline & 8 & $5030 \mathrm{~A}$ & $4182 \mathrm{~B}$ & 4047 B & $4607 \mathrm{AB}$ & $4120 \mathrm{~B}$ & \\
\hline \multirow{2}{*}{ Stems } & 0 & $730 \mathrm{~A}$ & $685 \mathrm{~A}$ & $790 \mathrm{~A}$ & $847 \mathrm{~A}$ & $682 \mathrm{~A}$ & 17.1 \\
\hline & 8 & $3002 \mathrm{~A}$ & $3015 \mathrm{~A}$ & $2985 \mathrm{~A}$ & $3002 \mathrm{~A}$ & $2682 \mathrm{~A}$ & \\
\hline \multirow{2}{*}{ Shoot } & 0 & $2425 \mathrm{~A}$ & $1992 \mathrm{~A}$ & $2240 \mathrm{~A}$ & $2425 \mathrm{~A}$ & $2117 \mathrm{~A}$ & 15.3 \\
\hline & 8 & $8032 \mathrm{~A}$ & 7197 AB & 7032 AB & $7610 \mathrm{AB}$ & $6802 \mathrm{~B}$ & \\
\hline \multirow{2}{*}{ Root } & 0 & $472 \mathrm{~A}$ & $395 \mathrm{~A}$ & $397 \mathrm{~A}$ & $460 \mathrm{~A}$ & $405 \mathrm{~A}$ & 16.8 \\
\hline & 8 & $1460 \mathrm{AB}$ & $1455 \mathrm{AB}$ & $1260 \mathrm{~B}$ & $1607 \mathrm{~A}$ & $1272 \mathrm{~B}$ & \\
\hline \multirow{2}{*}{ Whole plant } & 0 & $2897 \mathrm{~A}$ & $2387 \mathrm{~A}$ & $2637 \mathrm{~A}$ & $2885 \mathrm{~A}$ & $2522 \mathrm{~A}$ & 14.7 \\
\hline & 8 & $9492 \mathrm{~A}$ & $8652 A B$ & $8292 A B$ & $9217 \mathrm{AB}$ & 8075 B & \\
\hline
\end{tabular}

For each variable, means followed by different letters in the line are statistically different by the Tukey test $(P<0.05)$.

Martinez et al. (1993b,c) studied responses of 'Santa Rosa', 'UFV 1', and 'Doko' cultivars to different internal $\mathrm{P}$ levels. They observed that all cultivars showed increases in I max when cultivated in nutrient solution with low $\mathrm{P}$ concentration. Besides, UFV1 had a smaller kinetic adjustment than thetwo other cultivars. Moreover, 'Santa Rosa' and 'Doko' showed sharper decreases than 'UFV 1' in the shoot:root ratio, as well as greater $\mathrm{P}$ transport to the shoot. Such comparative results showed that the RSPi value was more important for the Pi homeostasis than adjustments in the kinetic parameters, the shoot:root ratio, and the P transport from the roots to the shoot for the studied soybean cultivars.

\section{CONCLUSIONS}

1. Thesize of non-metabol ic $P$ pools varied among cultivars; under $\mathrm{P}$ omission Po was maintained at the expense of $\mathrm{Pi}$, and the main sinks for therel eased $\mathrm{Pi}$ were the roots and upper leaves when the $\mathrm{P}$ supply was interrupted.

2. Main internal $P$ sources at the initial stress stage were upper and lower leaves and roots; at a later stage, roots becamethe main internal $\mathrm{P}$ source.

3. Under stress conditions, the cultivars differed in terms of the velocity of $\mathrm{Pi}$ release (RSPi) and internal buffering ability (IBCPi). The reduction in growth was directly related to IBCP $\mathrm{i}$ and inversely related to the RSPi.

\section{LITERATURE CITED}

ALVES, V.M.C. Frações de fósforo, de açúcares solúveis e de nitrogênio em quatro híbridos de milho submetidos a omissãoe ao ressuprimento defósforo. Viçosa, Universidade Federal de Viçosa, 1994. 106p. (Tese de Doutorado)

BIELESKI, R.L. \& FERGUSON, I.B. Physiology and metabolism of phosphate and its compounds. In: LAUCHLI, A. \& BIELESKI, R.L., eds. I norganic plant nutrition. New York, Springer-Verlag. 1983. p.422-449.

CLARK, R.B. Characterization of phosphatase of intact maize roots. J . Agric. Food Chem., 23:458-460, 1975.

CLARKSON, D.T. Factors affecting mineral nutrient acquisition by plants. Ann. Rev. Plant Physiol., 36:77-115, 1985.

COGLIATI, D.H. \& CLARKSON, D.T. Physiological changes in, and phosphate uptake by potato plants during development of and recovery from phosphate deficiency. Physiol. Plant., 58:287-294, 1983.

GLASS, A.D.M. \& SIDDQI, M.Y. The control of nutrient uptake rates in relation to the inorganic composition of plants. In: TINKER, P.B. \& LAUCHLI, A., eds. Advances in plant nutrition. New York, Praeger Publishers, 1984. p.103-147.

HOGUE, E.; WILCOX, G.E. \& CANTLIFFE, R.G. Effect of soil phosphorus levels on phosphate fractions in tomato leaves. J . Am. Soc. Hortic. Sci., 95:174-176, 1970.

LEE, R.B. \& RATCLIFFE, R.G. Phosphorus nutrition and the intracellular distribution of inorganic phosphatein pea root tips: a quantitative study using 31P-NMR. J . Exper. Bot., 34:1222-1224, 1983. 
LEE, R.B. \& RATCLIFFE, R.G. Nuclear magnetic resonance studies of location and function of plant nutrients in vivo. Plant Soil, 155/156:45-55, 1993.

MARTINEZ, H.E.P.; NOVAIS, R.F.; RODRIGUES, L.A.; SACRAMENTO, L.V.S. \& REIS J r., R.A. Reactions of three soybean cultivars to interruptions in phosphorus supply. In: FRAGOSO, M.A.C.; Van BEUSICHEM, M.L. \& HOWERS, A., eds. Optimization of plant nutrition. Wageningen, Kluwer Academic Publisher, 1993a. p.547554.

MARTINEZ, H.E.P.; NOVAIS, R.F.; RODRIGUES, L.A. \& SACRAMENTO, L.V.S. Comportamento de variedades de soja cultivadas sob diferentes níveis de fósforo. I. Cinética de absorção de fósforo e ajustes morfológicos da planta. R. Bras. Ci. Solo, 17:231-238, 1993b.
MARTINEZ, H.E.P.; NOVAIS, R.F.; SACRAMENTO, L.V.S. \& RODRIGUES, L.A. Comportamento de variedades de soja cultivadas sob diferentes níveis de fósforo. II. Translocação do fósforo absorvido e eficiência nutricional. R. Bras. Ci. Solo, 17:239-244, 1993c.

MUNIZ, A.S.; NOVAIS, R.F.; BARROS, N.F. \& NEVES, J .C.L. Nível crítico de fósforo na parte aérea de soja como variável do fator capacidade de fósforo no solo. R. Bras. Ci. Solo, 9:237-273, 1985.

NOVAIS, R.F . \& SMYTH,T.J . Fósforoem soloeplanta em condições tropicais. Viçosa, U niversidadeF ederal deViçosa, 1999. 399p.

RAGHOTHAMA, K.G. Phosphate acquisition. Ann. Rev. Plant Physiol. Plant Molec. Biol., 50:665-693. 1999.

RATCLIFFE, R.G. In vivo NMR studies of higher plants and algae. Adv. Bot. Res., 20:43-12, 1994. 
Hermínia Emília Prieto Martinez et al.

R. Bras. Ci. Solo, 29:249-257, 2005 